\title{
Albumin-to-Alkaline Phosphatase Ratio as a Novel Prognostic Marker of Nivolumab Monotherapy for Previously Treated Metastatic Renal Cell Carcinoma
}

\author{
MAKI YOSHINO $^{1}$, HIROKI ISHIHARA ${ }^{1}$, YUDAI ISHIYAMA ${ }^{1}$, HIDEKAZU TACHIBANA $^{1}$, DAISUKE TOKI $^{1}$, \\ KAORI YAMASHITA ${ }^{1}$, HIROHITO KOBAYASHI ${ }^{1}$, HIRONORI FUKUDA ${ }^{2}$, KAZUHIKO YOSHIDA ${ }^{2}$, \\ TOSHIO TAKAGI ${ }^{2}$, JUNPEI IIZUKA ${ }^{2}$, HIDEKI ISHIDA ${ }^{2}$, TSUNENORI KONDO ${ }^{1}$ and KAZUNARI TANABE ${ }^{2}$ \\ ${ }^{1}$ Department of Urology, Tokyo Women's Medical University Medical Center East, Arakawa, Japan; \\ ${ }^{2}$ Department of Urology, Tokyo Women's Medical University, Shinjuku, Japan
}

\begin{abstract}
Background/Aim: The relationship between albumin-to-alkaline phosphatase ratio $(A A P R)$ and the outcome of patients with metastatic renal cell carcinoma $(m R C C)$ treated with immune checkpoint inhibitors remains unresolved. We aimed to clarify the prognostic role of $A A P R$ in nivolumab monotherapy for previously treated $m R C C$. Patients and Methods: We retrospectively evaluated 60 patients with $m R C C$ treated with nivolumab after failure of at least one molecular targeted therapy. The patients were stratified into two groups based on the baseline AAPR. The threshold of AAPR was determined using receiver-operating characteristics and Youden index analyses. Overall survival $(O S)$, progression-free survival (PFS), and objective response rate (ORR) of nivolumab therapy were compared between the high and low AAPR groups. Results: The threshold of AAPR was set at 0.3, and 20 patients (33\%) were assigned to the low AAPR group. The median OS and PFS were significantly lower in the low AAPR group than those in the high group (OS: 8.3 months vs. not reached, $p<0.0001$; PFS: 2.9 vs. 10.4 months, $p=0.0006)$. Moreover, ORR was significantly lower in the low AAPR group than in the high group (16\% vs. $45 \%$, $p=0.0397)$. Multivariate analyses further showed that AAPR was an independent factor for OS [HR=0.27 (95\% CI=0.090.77), $p=0.0151]$ but not for PFS ( $p=0.174)$. Conclusion: Baseline AAPR was significantly associated with outcome in
\end{abstract}

This article is freely accessible online.

Correspondence to: Tsunenori Kondo, MD, Ph.D., Department of Urology, Tokyo Women's Medical University Medical Center East, 2-1-10 Nishiogu, Arakawa-ku, Tokyo 116-8567, Japan. Tel: +81 338101111, Fax: +81 358556319, e-mail: tkondo@twmu.ac.jp

Key Words: Kidney cancer, PD-1, biomarkers, ALP, immune checkpoint inhibitor. patients with $m R C C$ receiving nivolumab monotherapy and may, therefore, constitute an effective prognostic factor for nivolumab treatment.

Immune checkpoint inhibitors (ICIs) play an important role in the treatment of various types of cancers, including renal cell carcinoma (RCC) (1). Nivolumab is the first approved ICI for the treatment of metastatic RCC (mRCC) (2). In the current strategy of systemic therapy for $\mathrm{mRCC}$, nivolumab monotherapy as a second- or further-line therapy is not strongly recommended (3); however, nivolumab is still used in combination with ipilimumab (4) or cabozantinib (5) in a first-line setting. Therefore, nivolumab is still considered indispensable in the systematic therapy for mRCC.

A previous CheckMate 025 trial showed that nivolumab exhibits a higher anti-tumor effect than that of everolimus (2). However, the objective response rate (ORR) of nivolumab therapy remains $25 \%$, indicating that a certain number of patients do not benefit from this therapy. Therefore, we need to identify effective prognostic factors for patient selection in nivolumab therapy.

The albumin-to-alkaline phosphatase ratio (AAPR) was first reported to be associated with overall survival (OS) and disease-free survival in patients who received curative surgery for hepatocellular carcinoma (6). Subsequently, several studies have indicated that a low AAPR is associated with a worse patient outcome in metastatic nasopharyngeal carcinoma treated with chemotherapy (7), advanced hepatocellular carcinoma not treated with the standard chemotherapy (8), small-cell lung cancer treated with chemoradiotherapy (9), cervical cancer treated with surgery (10), pancreatic ductal carcinoma treated with chemotherapy (11), and non-metastatic RCC treated with curative nephrectomy (12). However, the prognostic role of AAPR in patients with $\mathrm{mRCC}$ treated with ICIs remains unknown. 
In this context, we retrospectively investigated the potential role of AAPR as a prognostic factor of outcome in patients that underwent nivolumab monotherapy for previously treated mRCC.

\section{Patients and Methods}

Patients. Sixty-eight patients who received nivolumab monotherapy after failure of at least one molecular targeted therapy for mRCC between June 2013 and February 2020 at our two institutions (Tokyo Women's Medical University Hospital, Tokyo, Japan, and Tokyo Women's Medical University Medical Center East, Tokyo, Japan) were evaluated. Among them, eight patients were excluded due to lack of clinical data, including serum albumin or alkaline phosphatase (ALP) levels. The remaining 60 patients were evaluated in this retrospective study.

All clinical and laboratory data were obtained from our electronic database and patient medical records. The study protocol was approved by the Institutional Ethics Review Board of the Tokyo Women's Medical University (ID: 2020-0009). The present study was performed in accordance with the principles outlined in the Declaration of Helsinki of 1964 and its later amendments. Due to the retrospective and observational nature of the study, the requirement of informed consent was waived.

Albumin-to-alkaline phosphatase ratio (AAPR). Patients were stratified into two groups based on a threshold of baseline (pretreatment) AAPR (for example, high and low). Subsequently, the overall survival (OS) and progression-free survival (PFS) were compared between the two groups. The threshold of AAPR was determined by generating a receiver operating characteristic (ROC) curve and performing maximum Youden index analyses for OS. In addition, we further compared the OS and PFS based on a change in AAPR at baseline and the initial AAPR three months after the initiation of nivolumab treatment. In patients whose treatment duration was less than 3 months, we determined the maximum AAPR during the entire duration of nivolumab treatment.

The method used for measuring ALP levels differs between Japan (Japan Society of Clinical Chemistry, JSCC) and western countries (International Federation of Clinical Chemistry, IFCC). Therefore, we multiplied an ALP value obtained via the JSCC method by 0.35 to correspond to the ALP value obtained via the IFCC method, and then we calculated the AAPR.

Protocol for nivolumab monotherapy. Nivolumab was intravenously administered every two weeks at a dose of $3 \mathrm{mg} / \mathrm{kg}$ or at a flat dose of $240 \mathrm{mg} / \mathrm{body}$. Dose modifications were not performed; however, the dosage interval could be modified based on the condition of the patient or in the case of adverse events. Post-treatment imaging examinations including plain or enhanced computed tomography, or magnetic resonance imaging of the chest, abdomen, and pelvis were conducted at regular intervals of 4-12 weeks depending on the condition of the patient. Nivolumab was administered until radiographic or clinical disease progression was observed, or intolerable adverse events occurred. The radiographic evaluation of tumor response was conducted according to the Response Evaluation Criteria in Solid Tumors version 1.1. (13).

Statistical analysis. We evaluated the OS and PFS after the initiation of nivolumab treatment. The data of patients lost to follow-up were
Table I. Patient characteristics.

\begin{tabular}{|c|c|c|c|c|}
\hline Variable & $\begin{array}{c}\text { All } \\
(\mathrm{n}=60)\end{array}$ & $\begin{array}{l}\text { High } \\
(\mathrm{n}=40)\end{array}$ & $\begin{array}{l}\text { Low } \\
(\mathrm{n}=20)\end{array}$ & $p$-Value \\
\hline \multicolumn{5}{|l|}{ Gender } \\
\hline Male (ref. female) & $48(80 \%)$ & $35(88 \%)$ & $13(65 \%)$ & 0.04 \\
\hline \multicolumn{5}{|l|}{ Age, years } \\
\hline \multicolumn{5}{|l|}{ Histopathology } \\
\hline Clear-cell carcinoma & $48(81 \%)$ & $33(83 \%)$ & $15(79 \%)$ & 0.74 \\
\hline $\begin{array}{l}\text { Non-clear-cell } \\
\text { carcinoma }\end{array}$ & $11(19 \%)$ & $7(17 \%)$ & $4(21 \%)$ & \\
\hline $\begin{array}{l}\text { IMDC risk at } \\
\text { nivolumab initiation }\end{array}$ & & & & 0.0049 \\
\hline Favorable & $2(3 \%)$ & $2(5 \%)$ & $0(0 \%)$ & \\
\hline Intermediate & $37(62 \%)$ & $30(75 \%)$ & $7(35 \%)$ & \\
\hline Poor & $20(33 \%)$ & $7(18 \%)$ & $13(65 \%)$ & \\
\hline \multicolumn{5}{|l|}{ KPS } \\
\hline$<80($ ref. $\geq 80)$ & $12(20 \%)$ & $4(10 \%)$ & $8(40 \%)$ & 0.0087 \\
\hline \multicolumn{5}{|l|}{$\begin{array}{l}\text { Number of prior } \\
\text { systemic therapies }\end{array}$} \\
\hline 1 & $33(57 \%)$ & $22(56 \%)$ & $11(58 \%)$ & 0.91 \\
\hline$\geq 2$ & $25(43 \%)$ & $17(44 \%)$ & $8(42 \%)$ & \\
\hline \multicolumn{5}{|l|}{$\begin{array}{l}\text { Number of } \\
\text { metastatic organs }\end{array}$} \\
\hline 1 & $20(33 \%)$ & $14(35 \%)$ & $6(30 \%)$ & 0.69 \\
\hline$\geq 2$ & $40(67 \%)$ & $26(65 \%)$ & $14(70 \%)$ & \\
\hline \multicolumn{5}{|l|}{ Liver metastasis } \\
\hline Yes (ref. No) & $9(15 \%)$ & $3(8 \%)$ & $6(30 \%)$ & 0.0256 \\
\hline $\begin{array}{l}\text { Alb g/L* } \\
\text { (continuous variable) }\end{array}$ & $33(28-38)$ & $37(33-39)$ & $26(22-31)$ & $<0.0001$ \\
\hline Alb $<$ LLN & $32(53 \%)$ & $13(33 \%)$ & $19(95 \%)$ & $<0.0001$ \\
\hline ALP U/L* & $\begin{array}{c}87.3 \\
(736-110)\end{array}$ & $\begin{array}{c}81.5 \\
(650-893)\end{array}$ & $\begin{array}{c}126.5 \\
(1088-1866)\end{array}$ & $<0.0001$ \\
\hline (continuous variable) & $(73.6-110)$ & $(65.0-89.3)$ & $(108.8-186.6)$ & \\
\hline ALP $>$ ULN & $14(23 \%)$ & $0(0 \%)$ & $14(0 \%)$ & $<0.0001$ \\
\hline $\begin{array}{l}\text { AAPR* } \\
\text { (continuous variable) }\end{array}$ & $\begin{array}{c}0.38 \\
(0.24-0.49)\end{array}$ & $\begin{array}{c}0.45 \\
(0.37-0.58)\end{array}$ & $\begin{array}{c}0.19 \\
(0.13-0.24)\end{array}$ & $<0.0001$ \\
\hline $\begin{array}{l}\text { Follow-up } \\
\text { period, months* }\end{array}$ & $\begin{array}{c}20.8 \\
(6.9-29.3)\end{array}$ & $\begin{array}{c}21.8 \\
(9.2-36.2)\end{array}$ & $\begin{array}{c}7.8 \\
(1.5-25.4)\end{array}$ & 0.0125 \\
\hline
\end{tabular}

*Median (interquartile range). IMDC, International Metastatic Renal Cell Carcinoma Database Consortium; KPS, Karnofsky performance status; LLN, lower limit of normal; ULN, upper limit of normal; AAPR, albuminto-alkaline phosphatase ratio; Alb, albumin; ALP, alkaline phosphatase.

censored at the time of last contact. Survival data were collected until the end of September 2020. Survival was calculated using the Kaplan-Meier method and compared using the log-rank test. Univariate and multivariate analyses using the Cox proportional hazard regression models were conducted to identify risk factors for OS and PFS. Risk was expressed as hazard ratios (HRs) with $95 \%$ confidence intervals (CIs). All statistical analyses were performed using JMP version 15 (SAS Institute Inc., Cary, NC, USA); a value of $p<0.05$ was considered significant.

\section{Results}

Patient characteristics. An AAPR threshold of 0.30 was determined based on the ROC curve and the maximum 
A
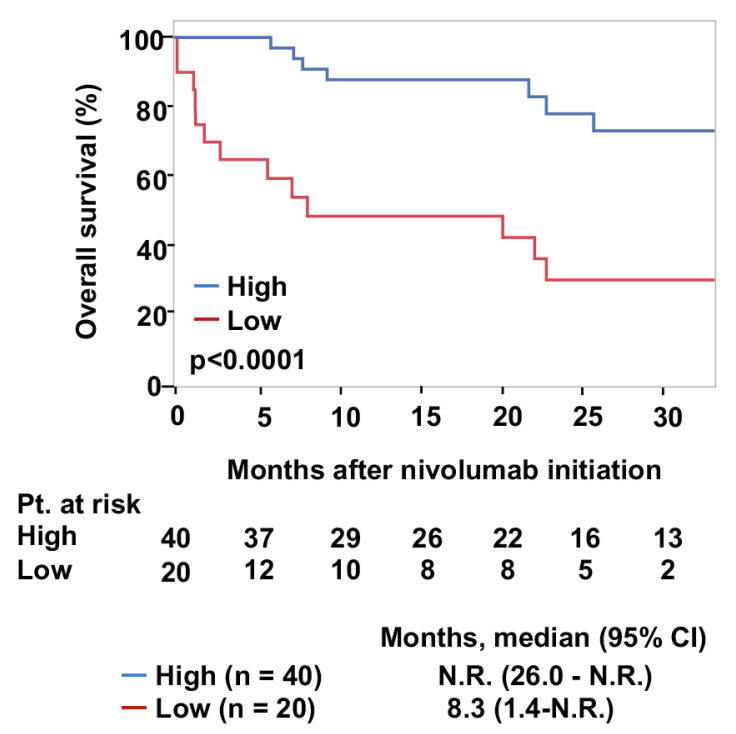

B

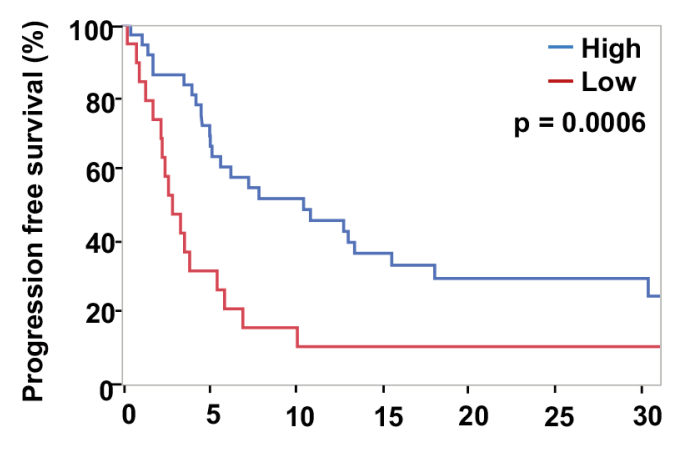

Months after nivolumab initiation

\begin{tabular}{lccccccc}
$\begin{array}{l}\text { Pt. at risk } \\
\text { High }\end{array}$ & 40 & 26 & 17 & 11 & 8 & 8 & 6 \\
Low & 20 & 6 & 3 & 3 & 3 & 3 & 2 \\
& & \multicolumn{5}{c}{ Months, median $(95 \% \mathrm{CI})$} \\
& - High $(\mathrm{n}=40)$ & \multicolumn{3}{c}{$10.4(5.1-15.1)$} \\
& - Low $(\mathrm{n}=20)$ & \multicolumn{4}{c}{$2.9(1.8-5.5)$}
\end{tabular}

Figure 1. Survival according to baseline AAPR. (A) Overall survival and (B) progression-free survival. AAPR, Albumin-to-alkaline phosphatase ratio; CI, confidence interval; N.R., not reached.

Youden index analyses. The area under the curve of AAPR was 0.69 , and this value was higher than those of single albumin (0.65) and ALP levels (0.57). Based on the threshold of AAPR, the patients were classified into high $(\geq 0.3)$ and low $(<0.3)$ AAPR groups.

The clinicopathological characteristics of the patients are summarized in Table I. Forty (67\%) and twenty (33\%) patients were assigned to the high and low AAPR groups, respectively. The number of patients classified as poor risk by the International Metastatic Renal Cell Carcinoma Database Consortium (IMDC) was significantly higher in the low group than in the high group ( $33 \%$ vs. $18 \%, p=0.0006$ ) (Table I). In contrast, there was no significant difference in other factors, including sex, age, histopathology, number of prior systematic therapies, or number of metastatic organs (all $p>0.05$ ).

Survival according to baseline AAPR. The median follow-up duration was 20.8 months (interquartile range $=7.40-32.8$ ). During the follow-up, $44(73 \%)$ patients showed disease progression and 21 (37\%) patients died due to any cause. OS was significantly lower in the low AAPR group than in the high group [median: 8.3 (95\% CI=1.4 - not reached (N.R.)) $v s$. N.R. (N.R.-N.R.) months, $p<0.0001]$ (Figure 1A). PFS was significantly lower in the low AAPR group than in the high group [median: 2.9 (95\% CI=1.8-5.5) vs. 10.5 (5.115.1) months, $p=0.0009$ ] (Figure 1B).

Univariate analysis for OS showed that the AAPR was a significant factor, together with histopathology and IMDC risk (all, $p<0.05$ ). Multivariate analysis using these factors further showed that the AAPR was an independent factor for OS (HR $=0.27,95 \% \mathrm{CI}=0.09-0.77, p=0.0151) \quad$ (Table II). Univariate analysis for PFS showed that the AAPR was a significant factor, together with sex, histopathology, and IMDC risk (14) (all, $p<0.05)$; however, multivariate analysis using these factors showed that none of them were independent factors (all, $p>0.05$ ) (Table III).

ORR according to baseline AAPR. The ORR according to the AAPR is shown in Figure 2. Complete response, partial response, stable disease, and progressive disease were observed in five (13\%), $12(32 \%), 13(32 \%)$, and $10(23 \%)$ patients in the high AAPR group, and in $0(0 \%)$, three (16\%), six (32\%), and $11(52 \%)$ patients in the low group, respectively. ORR was significantly lower in the low AAPR group than in the high group ( $16 \% v s .45 \%, p=0.0397)$.

Survival according to the change in AAPR. To further analyze the prognostic role of AAPR, we stratified the patients into three groups based on the change in AAPR within the initial three months after the initiation of nivolumab treatment. Twenty patients whose baseline AAPR was low and AAPR during three months post-treatment remained low $(<0.3)$ were assigned to a remained-low group. Twenty-three patients whose baseline AAPR was high and AAPR during three months post-treatment declined to low were assigned to a declined group. Seventeen patients whose baseline AAPR was high and AAPR during at the three months posttreatment remained high $(\geq 0.3)$ were assigned to the 
Table II. Univariate and multivariate analyses of overall survival.

\begin{tabular}{|c|c|c|c|c|}
\hline & $\begin{array}{c}\text { Univariate } \\
\text { HR }(95 \% \mathrm{CI})\end{array}$ & $p$-Value & $\begin{array}{l}\text { Multivariate } \\
\text { HR (95\% CI) }\end{array}$ & $p$-Value \\
\hline \multicolumn{5}{|l|}{ Age, years } \\
\hline$>65$ (ref. $\leq 65)$ & $1.40(0.55-3.51)$ & 0.470 & & \\
\hline \multicolumn{5}{|l|}{ Gender } \\
\hline Male (ref. female) & $0.41(0.15-1.08)$ & 0.0723 & & \\
\hline \multicolumn{5}{|l|}{ Histopathology } \\
\hline Clear-cell carcinoma (ref. non-clear cell carcinoma) & $0.32(0.12-0.89)$ & 0.0266 & $0.41(0.15-1.14)$ & 0.0896 \\
\hline \multicolumn{5}{|l|}{ IMDC risk at nivolumab initiation } \\
\hline Poor (ref. favorable/intermediate) & $2.70(1.11-6.55)$ & 0.0279 & $1.32(0.48-3.61)$ & 0.577 \\
\hline \multicolumn{5}{|l|}{ Number of metastatic organs } \\
\hline$\geq 2($ ref. $<2)$ & $0.56(0.23-1.37)$ & 0.212 & & \\
\hline \multicolumn{5}{|l|}{ Liver metastasis } \\
\hline Yes (ref. no) & $1.99(0.66-5.98)$ & 0.221 & & \\
\hline \multicolumn{5}{|l|}{ AAPR } \\
\hline High (ref. low) & $0.20(0.08-0.52)$ & 0.0009 & $0.27(0.09-0.77)$ & 0.0151 \\
\hline
\end{tabular}

CI, Confidence interval; HR, hazard ratio; IMDC, International Metastatic Renal Cell Carcinoma Database Consortium; AAPR, albumin-to-alkaline phosphatase ratio.

Table III. Univariate and multivariate analyses of progression-free survival.

\begin{tabular}{|c|c|c|c|c|}
\hline & $\begin{array}{c}\text { Univariate } \\
\text { HR }(95 \% \text { CI) }\end{array}$ & $p$-Value & $\begin{array}{l}\text { Multivariate } \\
\text { HR (95\% CI) }\end{array}$ & $p$-Value \\
\hline \multicolumn{5}{|l|}{ Age, years } \\
\hline$>65($ ref. $\leq 65)$ & $0.77(0.42-1.40)$ & 0.399 & & \\
\hline \multicolumn{5}{|l|}{ Gender } \\
\hline Male (ref. female) & $0.39(0.19-0.81)$ & 0.0116 & $0.49(0.22-1.07)$ & 0.0770 \\
\hline \multicolumn{5}{|l|}{ Histopathology } \\
\hline Clear-cell carcinoma (ref. non-clear cell carcinoma) & $0.36(0.16-0.79)$ & 0.0113 & $0.60(0.25-1.43)$ & 0.253 \\
\hline \multicolumn{5}{|l|}{ IMDC risk at nivolumab initiation } \\
\hline Poor (ref. favorable/intermediate) & $1.83(0.99-3.38)$ & 0.0526 & $1.30(0.65-2.66)$ & 0.445 \\
\hline \multicolumn{5}{|l|}{ Number of metastatic organs } \\
\hline$\geq 2($ ref. $<2)$ & $0.72(0.39-1.33)$ & 0.296 & & \\
\hline \multicolumn{5}{|l|}{ Liver metastasis } \\
\hline Yes (ref. no) & $1.14(0.47-2.71)$ & 0.764 & & \\
\hline \multicolumn{5}{|l|}{ AAPR } \\
\hline High (ref. low) & $0.42(0.22-0.79)$ & 0.0069 & $0.60(0.29-1.24)$ & 0.174 \\
\hline
\end{tabular}

CI, Confidence interval; HR, hazard ratio; KPS, Karnofsky performance status; AAPR, albumin to alkaline phosphatase ratio.

remained-high group. When the OS was compared among the three groups, OS values were significantly different [median: 8.3 (95\% CI=1.4-NR) vs. N.R. (23.1- N.R.) vs. N.R. (95\% $\mathrm{CI}=7.4-\mathrm{N} . \mathrm{R}$.) months, $p=0.0003$ ] (Figure 3A). Additionally, PFS was significantly different among the three groups [median: $2.9(95 \% \mathrm{CI}=1.8-5.5)$ vs. $7.6(5.0-12.7)$ vs. 17.9 (95\% CI=1.8-NR) months, $p=0.0036$ ] (Figure 3B).

\section{Discussion}

In this retrospective study, we found that AAPR may play a potential role in determining the outcomes of nivolumab monotherapy for previously treated mRCC. A low AAPR was significantly associated with a relatively poorer OS and PFS. Further, multivariate analysis showed that the AAPR was an independent factor for OS. In addition, a low AAPR was significantly associated with a relatively lower ORR.

An association between AAPR and outcome in patients has been observed in various types of cancer, including genitourinary cancer. Particularly, in non-metastatic upper tract urothelial carcinoma and non-metastatic RCC, a significant association between AAPR and outcome was observed $(12,15-17)$. To the best of our knowledge, this is the first study that demonstrated that AAPR was 


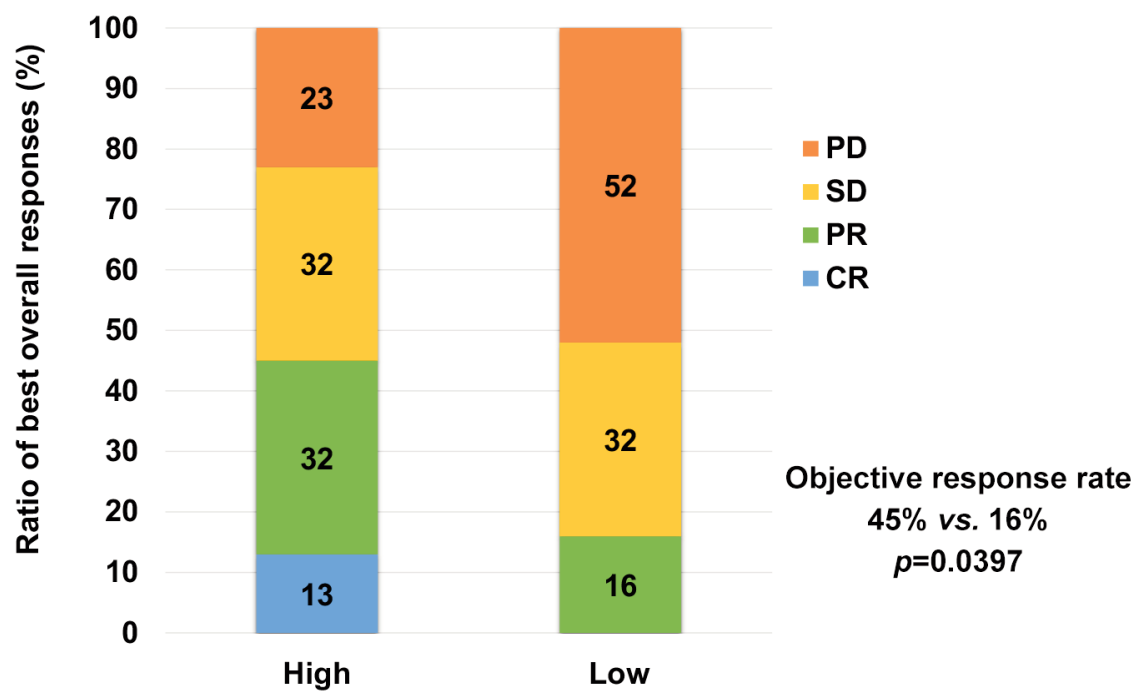

Figure 2. Objective response rate according to baseline AAPR. CR, Complete response; PR, partial response; SD, stable disease; PD, progressive disease.

A

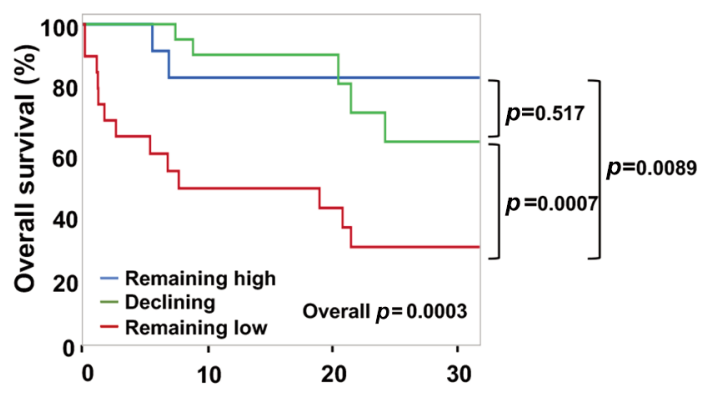

Months after nivolumab initiation
B

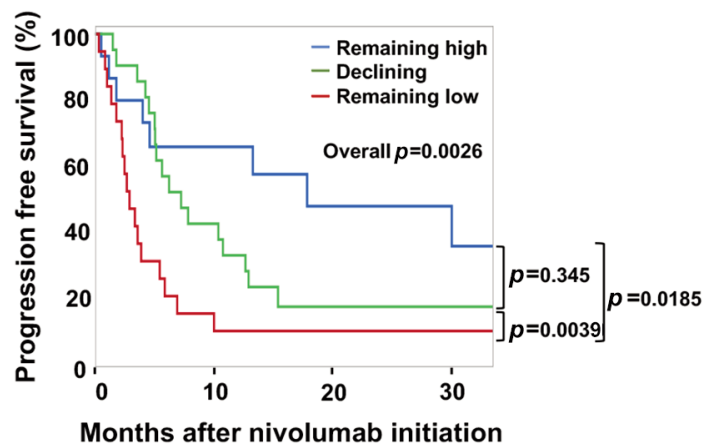

\begin{tabular}{ccc}
11 & 9 & 7 \\
19 & 12 & 7 \\
9 & 8 & 3 \\
\multicolumn{3}{c}{ Months, median (95\% CI) } \\
\multicolumn{3}{c}{ N.R. (7.4 - N.R.) } \\
\multicolumn{3}{c}{ N.R. $(23.1-$ N.R.) } \\
\multicolumn{3}{c}{$8.3(1.4-$ N.R. }
\end{tabular}

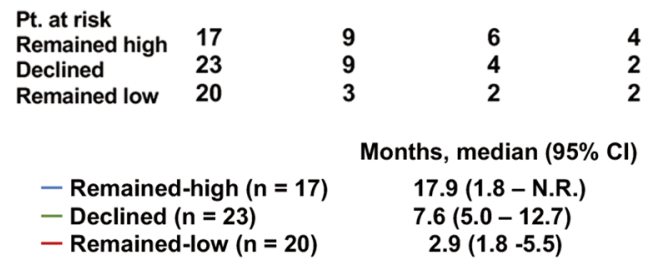

Figure 3. Survival according to changes in AAPR during the initial three months after treatment. (A) Overall survival and (B) progression-free survival. AAPR, Albumin-to-alkaline phosphatase ratio; CI, confidence interval; N.R., not reached.

significantly associated with the outcome of nivolumab monotherapy for mRCC.

The mechanism underlying the association between AAPR and disease outcome is still not understood. Albumin is a serum protein synthesized in the liver, and its level reflects the nutritional and inflammatory statuses $(6,18)$. The development of hypoalbuminemia is associated with a reduced immunological anti-tumor response via suppression of T cell activity $(19,20)$. Multiple studies have indicated a significant association of serum albumin level with survival in patients with cancer (21-24). ALP is a hydrolase enzyme primarily synthesized in the bile duct, liver, kidney, and bone, and the levels of ALP increase in liver disease, kidney disease, and bone metastasis of cancer. In addition, ALP is 
synthesized by cancer cells, and regulates tumor development via suppression of inflammatory signals, and induces the immune response by regulating purinergic signals $(25,26)$.

Several prognostic factors that reflect systemic inflammatory or nutritional statuses, which can be assessed using routine blood tests, have been identified in ICIs including nivolumab for treating mRCC (27-33). As the AAPR is calculated based on the ALP and albumin levels, patients do not need to undergo expensive or invasive tests for assessing this factor.

By performing the subgroup analysis based on the AAPR change, we found a comparable survival between the remained-high and declined-groups, and a lower survival in the remained-low group. This finding suggested that the baseline AAPR, rather than the change in value, was closely associated with survival of patients treated with nivolumab.

There are several limitations in this study. First, a selection bias may exist since this study was retrospectively designed and conducted only at two Institutions with a small sample size. Second, we evaluated patients that received nivolumab monotherapy as second- or further-line therapy based on a previous guideline (34), although this protocol is not strongly recommended in the current guidelines (3). Third, we determined the threshold of AAPR as 0.30 in this study; however, the value varies across different studies (12, 16). Therefore, further studies are needed to determine the optimal threshold value of AAPR in mRCC. Despite these limitations, to the best of our knowledge, this is the first study indicating the significant association of AAPR with ICI therapy. Currently, ICIs play a central role in systemic therapy for mRCC, and several regimens can be used as the first-line therapy (4). However, effective predictive or prognostic factors for ICIs remain unidentified. Thus, further studies assessing the value of AAPR as a prognostic marker in other ICI-based regimens are needed to develop more effective systemic treatment protocols for mRCC.

In conclusion, this retrospective study indicated that AAPR may be significantly associated with the outcome of nivolumab monotherapy used as a second- or further-line therapy for previously treated mRCC. This novel factor can be used for outcome prediction; however, further prospective studies are needed to validate our findings.

\section{Conflicts of Interest}

Tsunenori Kondo received honoraria from Novartis, Pfizer, and Bristol-Myers Squibb and Ono Pharmaceutical. Toshio Takagi received honoraria from Pfizer and Bristol-Myers Squibb and Ono Pharmaceutical.

\section{Authors' Contributions}

Tsunenori Kondo conceived the study. Maki Yoshino designed and analyzed the data. Maki Yoshino and Hiroki Ishihara drafted the manuscript. All Authors revised the article for important intellectual content, reviewed the data and their analysis, and approved this article.

\section{References}

1 Rotte A, Jin JY and Lemaire V: Mechanistic overview of immune checkpoints to support the rational design of their combinations in cancer immunotherapy. Ann Oncol 29(1): 7183, 2018. PMID: 29069302. DOI: 10.1093/annonc/mdx686

2 Motzer RJ, Escudier B, McDermott DF, George S, Hammers HJ, Srinivas S, Tykodi SS, Sosman JA, Procopio G, Plimack ER, Castellano D, Choueiri TK, Gurney H, Donskov F, Bono P, Wagstaff J, Gauler TC, Ueda T, Tomita Y, Schutz FA, Kollmannsberger C, Larkin J, Ravaud A, Simon JS, Xu LA, Waxman IM, Sharma P and CheckMate 025 Investigators: Nivolumab versus everolimus in advanced renal-cell carcinoma. N Engl J Med 373(19): 1803-1813, 2015. PMID: 26406148. DOI: $10.1056 /$ NEJMoa1510665

3 Albiges L, Powles T, Staehler M, Bensalah K, Giles RH, Hora M, Kuczyk MA, Lam TB, Ljungberg B, Marconi L, Merseburger AS, Volpe A, Abu-Ghanem Y, Dabestani S, Fernández-Pello S, Hofmann F, Kuusk T, Tahbaz R and Bex A: Updated European Association of Urology guidelines on renal cell carcinoma: Immune checkpoint inhibition is the new backbone in first-line treatment of metastatic clear-cell renal cell carcinoma. Eur Urol 76(2): 151-156, 2019. PMID: 31151678. DOI: $10.1016 /$ j.eururo.2019.05.022

4 Motzer RJ, Tannir NM, McDermott DF, Arén Frontera O, Melichar B, Choueiri TK, Plimack ER, Barthélémy P, Porta C, George S, Powles T, Donskov F, Neiman V, Kollmannsberger CK, Salman P, Gurney H, Hawkins R, Ravaud A, Grimm MO, Bracarda S, Barrios CH, Tomita Y, Castellano D, Rini BI, Chen AC, Mekan S, McHenry MB, Wind-Rotolo M, Doan J, Sharma P, Hammers HJ, Escudier B and CheckMate 214 Investigators: Nivolumab plus ipilimumab versus sunitinib in advanced renalcell carcinoma. N Engl J Med 378(14): 1277-1290, 2018. PMID: 29562145. DOI: 10.1056/NEJMoa1712126

5 Choueiri TK, Powles T, Burotto M, Escudier B, Bourlon MT, Zurawski B, Oyervides Juárez VM, Hsieh JJ, Basso U, Shah AY, Suárez C, Hamzaj A, Goh JC, Barrios C, Richardet M, Porta C, Kowalyszyn R, Feregrino JP, Żołnierek J, Pook D, Kessler ER, Tomita Y, Mizuno R, Bedke J, Zhang J, Maurer MA, Simsek B, Ejzykowicz F, Schwab GM, Apolo AB, Motzer RJ and CheckMate 9ER Investigators: Nivolumab plus cabozantinib versus sunitinib for advanced renal-cell carcinoma. N Engl J Med 384(9): 829-841, 2021. PMID: 33657295. DOI: 10.1056/ NEJMoa2026982

6 Chan AW, Chan SL, Mo FK, Wong GL, Wong VW, Cheung YS, Chan HL, Yeo W, Lai PB and To KF: Albumin-to-alkaline phosphatase ratio: a novel prognostic index for hepatocellular carcinoma. Dis Markers 2015: 564057, 2015. PMID: 25737613. DOI: $10.1155 / 2015 / 564057$

7 Nie M, Sun P, Chen C, Bi X, Wang Y, Yang H, Liu P, Li Z, Xia $\mathrm{Y}$ and Jiang W: Albumin-to-alkaline phosphatase ratio: A novel prognostic index of overall survival in cisplatin-based chemotherapy-treated patients with metastatic nasopharyngeal carcinoma. J Cancer 8(5): 809-815, 2017. PMID: 28382143. DOI: $10.7150 /$ jca.17536

8 Cai X, Chen Z, Chen J, Ma X, Bai M, Wang T, Chen X, Wu D, Wei L, Li X, Lin Q, Wen J, Ruan D, Lin Z, Dong M and Wu X: 
Albumin-to-alkaline phosphatase ratio as an independent prognostic factor for overall survival of advanced hepatocellular carcinoma patients without receiving standard anti-cancer therapies. J Cancer 9(1): 189-197, 2018. PMID: 29290785. DOI: $10.7150 /$ jca. 21799

9 Li X, Li B, Zeng H, Wang S, Sun X, Yu Y, Wang L and Yu J: Prognostic value of dynamic albumin-to-alkaline phosphatase ratio in limited stage small-cell lung cancer. Future Oncol 15(9): 995-1006, 2019. PMID: 30644319. DOI: 10.2217/fon-2018-0818

10 Zhang C, Li Y, Ji R, Zhang W, Zhang C, Dan Y, Qian H and He A: The prognostic significance of pretreatment albumin/alkaline phosphatase ratio in patients with stage IB-IIA cervical cancer. Onco Targets Ther 12: 9559-9568, 2019. PMID: 32009792. DOI: 10.2147/OTT.S225294

11 Zhang K, Dong S, Jing YH, Gao HF, Chen LY, Hua YQ, Chen $\mathrm{H}$ and Chen $\mathrm{Z}$ : Albumin-to-alkaline phosphatase ratio serves as a prognostic indicator in unresectable pancreatic ductal adenocarcinoma: a propensity score matching analysis. BMC Cancer 20(1): 541, 2020. PMID: 32517802. DOI: 10.1186/ s12885-020-07023-9

12 Xia A, Chen Y, Chen J, Pan Y, Bao L and Gao X: Prognostic value of the albumin-to-alkaline phosphatase ratio on urologic outcomes in patients with non-metastatic renal cell carcinoma following curative nephrectomy. J Cancer 10(22): 5494-5503, 2019. PMID: 31632493. DOI: 10.7150/jca.34029

13 Eisenhauer EA, Therasse P, Bogaerts J, Schwartz LH, Sargent D, Ford R, Dancey J, Arbuck S, Gwyther S, Mooney M, Rubinstein L, Shankar L, Dodd L, Kaplan R, Lacombe D and Verweij J: New response evaluation criteria in solid tumours: revised RECIST guideline (version 1.1). Eur J Cancer 45(2): 228-247, 2009. PMID: 19097774. DOI: 10.1016/j.ejca.2008. 10.026

14 Ko J, Xie W, Kroeger N, Lee J, Rini B, Knox J, Bjarnason G, Srinivas S, Pal S, Yuasa T, Smoragiewicz M, Donskov F, Kanesvaran R, Wood L, Ernst D, Agarwal N, Vaishampayan U, Rha S, Choueiri T and Heng D: The International Metastatic Renal Cell Carcinoma Database Consortium model as a prognostic tool in patients with metastatic renal cell carcinoma previously treated with first-line targeted therapy: a populationbased study. The Lancet Oncology 16(3): 293-300, 2019. DOI: 10.1016/s1470-2045(14)71222-7

15 Tan P, Xie N, Ai J, Xu H, Xu H, Liu L, Yang L and Wei Q: The prognostic significance of Albumin-to-Alkaline Phosphatase Ratio in upper tract urothelial carcinoma. Sci Rep 8(1): 12311, 2018. PMID: 30120312. DOI: 10.1038/s41598-018-29833-5

$16 \mathrm{Hu}$ X, Yang ZQ, Dou WC, Shao YX, Wang YH, Lia T and Li X: Validation of the prognostic value of preoperative albumin-toalkaline phosphatase ratio in patients with surgically treated nonmetastatic renal cell carcinoma. Onco Targets Ther 13: 82878297, 2020. PMID: 32903862. DOI: 10.2147/OTT.S264217

17 Sheth KR, Haddad AQ, Ashorobi OS, Meissner MA, Sagalowsky AI, Lotan Y and Margulis V: Prognostic serum markers in patients with high-grade upper tract urothelial carcinoma. Urol Oncol 34(9): 418.e9-418.e16, 2016. PMID: 27234379. DOI: 10.1016/j.urolonc.2016.04.009

18 Arroyo V, García-Martinez R and Salvatella X: Human serum albumin, systemic inflammation, and cirrhosis. J Hepatol 61(2): 396-407, 2014. PMID: 24751830. DOI: 10.1016/j.jhep.2014.04.012

19 Alwarawrah Y, Kiernan K and MacIver NJ: Changes in nutritional status impact immune cell metabolism and function.
Front Immunol 9: 1055, 2018. PMID: 29868016. DOI: 10.3389/ fimmu.2018.01055

20 Grivennikov SI, Greten FR and Karin M: Immunity, inflammation, and cancer. Cell 140(6): 883-899, 2010. PMID: 20303878. DOI: $10.1016 /$ j.cell.2010.01.025

21 Tanriverdi O, Avci N, Oktay E, Kalemci S, Pilanci KN, Cokmert S, Menekse S, Kocar M, Sen CA, Akman T, Ordu C, Goksel G, Meydan N and Barutca S: Pretreatment serum albumin level is an independent prognostic factor in patients with stage IIIB nonsmall cell lung cancer: A study of the Turkish Descriptive Oncological Researches Group. Asian Pac J Cancer Prev 16(14): 5971-5976, 2015. PMID: 26320482. DOI: 10.7314/apjcp. 2015.16.14.5971

22 González-Trejo S, Carrillo JF, Carmona-Herrera DD, BazGutiérrez P, Herrera-Goepfert R, Núñez G, Ochoa-Carrillo FJ, Gallardo-Rincón D, Aiello-Crocifoglio V and Oñate-Ocaña LF: Baseline serum albumin and other common clinical markers are prognostic factors in colorectal carcinoma: A retrospective cohort study. Medicine (Baltimore) 96(15): e6610, 2017. PMID: 28403106. DOI: 10.1097/MD.0000000000006610

$23 \mathrm{Ku} \mathrm{JH}$, Kim M, Choi WS, Kwak C and Kim HH: Preoperative serum albumin as a prognostic factor in patients with upper urinary tract urothelial carcinoma. Int Braz J Urol 40(6): 753762, 2014. PMID: 25615244. DOI: 10.1590/S1677-5538.IBJU. 2014.06.06

24 Gupta D and Lis CG: Pretreatment serum albumin as a predictor of cancer survival: a systematic review of the epidemiological literature. Nutr J 9: 69, 2010. PMID: 21176210. DOI: 10.1186/ 1475-2891-9-69

25 Rao SR, Snaith AE, Marino D, Cheng X, Lwin ST, Orriss IR, Hamdy FC and Edwards CM: Tumour-derived alkaline phosphatase regulates tumour growth, epithelial plasticity and disease-free survival in metastatic prostate cancer. Br J Cancer 116(2): 227-236, 2017. PMID: 28006818. DOI: 10.1038/ bjc. 2016.402

26 Xie H, Wei L, Tang S and Gan J: Prognostic value of pretreatment albumin-to-alkaline phosphatase ratio in cancer: a meta-analysis. Biomed Res Int 2020: 6661097, 2020. PMID: 33376729. DOI: 10.1155/2020/6661097

27 Ramankulov A, Lein M, Kristiansen G, Meyer HA, Loening SA and Jung K: Elevated plasma osteopontin as marker for distant metastases and poor survival in patients with renal cell carcinoma. J Cancer Res Clin Oncol 133(9): 643-652, 2007. PMID: 17479289. DOI: 10.1007/s00432-007-0215-Z

28 Bilen MA, Dutcher GMA, Liu Y, Ravindranathan D, Kissick HT, Carthon BC, Kucuk O, Harris WB and Master VA: Association between pretreatment neutrophil-to-lymphocyte ratio and outcome of patients with metastatic renal-cell carcinoma treated with nivolumab. Clin Genitourin Cancer 16(3): e563-e575, 2018. PMID: 29402706. DOI: 10.1016/j.clgc.2017.12.015

29 Klatte T, Rossi SH and Stewart GD: Prognostic factors and prognostic models for renal cell carcinoma: a literature review. World J Urol 36(12): 1943-1952, 2018. PMID: 29713755. DOI: 10.1007/s00345-018-2309-4

30 Ishihara H, Tachibana H, Takagi T, Kondo T, Fukuda H, Yoshida $\mathrm{K}$, Iizuka J, Kobayashi H, Okumi M, Ishida $\mathrm{H}$ and Tanabe $\mathrm{K}$ : Predictive impact of peripheral blood markers and C-reactive protein in nivolumab therapy for metastatic renal cell carcinoma. Target Oncol 14(4): 453-463, 2019. PMID: 31359231. DOI: $10.1007 / \mathrm{s} 11523-019-00660-6$ 
31 Suzuki K, Terakawa T, Furukawa J, Harada K, Hinata N, Nakano $\mathrm{Y}$ and Fujisawa $\mathrm{M}$ : C-reactive protein and the neutrophil-to-lymphocyte ratio are prognostic biomarkers in metastatic renal cell carcinoma patients treated with nivolumab. Int J Clin Oncol 25(1): 135-144, 2020. PMID: 31512006 . DOI: 10.1007/s10147-019-01528-5

32 Takemura K, Yuasa T, Inamura K, Amori G, Koga F, Board PG and Yonese J: Impact of serum $\gamma$-glutamyltransferase on overall survival in patients with metastatic renal cell carcinoma in the era of targeted therapy. Target Oncol 15(3): 347-356, 2020. PMID: 32474759. DOI: 10.1007/s11523-020-00719-9

33 Ishihara H, Takagi T, Kondo T, Fukuda H, Tachibana H, Yoshida $\mathrm{K}$, Iizuka J, Okumi M, Ishida $\mathrm{H}$ and Tanabe K: Predictive impact of an early change in serum $\mathrm{C}$-reactive protein levels in nivolumab therapy for metastatic renal cell carcinoma. Urol Oncol 38(5): 526-532, 2020. PMID: 31864934. DOI: 10.1016/ j.urolonc.2019.12.008
34 Powles T, Staehler M, Ljungberg B, Bensalah K, Canfield SE, Dabestani S, Giles R, Hofmann F, Hora M, Kuczyk MA, Lam T, Marconi L, Merseburger AS, Volpe A and Bex A: Updated EAU guidelines for clear cell renal cancer patients who fail VEGF targeted therapy. Eur Urol 69(1): 4-6, 2016. PMID: 26508312. DOI: 10.1016/j.eururo.2015.10.017

Received May 30, 2021

Revised June 23, 2021

Accepted June 25, 2021 